\title{
JEJARING BAWASLU DALAM PENANGANAN PELANGGARAN PEMILIHAN UMUM SERENTAK
}

\author{
${ }^{1}$ Andi Setiawan \\ ${ }^{2}$ Hilmi Handala \\ Program Studi Ilmu Pemerintahan, Fakultas Ilmu Sosial dan Ilmu Politik, \\ Universitas Brawijaya. \\ JL. Veteran Malang, 65145 \\ Email: andi.setiawan@ub.ac.id
}

\begin{abstract}
Abstrak
Tulisan ini mengkaji tentang Badan Pengawas Pemilu Republik Indonesia yang kemudian disebut dengan Bawaslu RI dalam menjalankan fungsinya sebagai salah satu dari tiga lembaga penyelenggara pemilu di Indonesia. Pemilihan Umum atau Pemilu Serentak dilaksanakan pada tahun 2019 dimana memiliki kompleksitas masalah dari Pemilu pada umumnya, hal ini dikarenakan ruang lingkup yang begitu luas. Tulisan ini bertujuan untuk memaparkan langkah strategis dalam menjalankan fungsi lembaga melalui hubungan antar lembaga dengan Stakeholders. Tulisan ini menggunakan metode kualitatif yang datanya disajikan dalam bentuk deskriptif oleh penulis. Kerangka Konseptual yang digunakan dalam penelitian ini adalah Nework Governance oleh Klijn, Koppenjan, \& Termeer hal ini dikarenakan sesuai dengan tujuan penulis untuk melihat bagaimana hubungan antar lembaga dengan Stakeholders dijalankan. Hasil penelitian ini menunjukan bahwa Bawaslu RI dalam menjalankan fungsi pengawasannya melakukan hubungan antar lembaga yang dikategorikan menjadi empat subjek yaitu: (1)Lembaga Pemerintah, (2)Non Government Organization $(N G O)$, (3)Perguruan Tinggi, dan (4)Media. Dalam menjalankan hubungan antar lembaga tersebut telah diimplementasikan dalam Network Governance yaitu membentuk persepsi/interpretasi, menentukan aktor/sumberdaya, dan membangun institusi/norma. Kemudian, melalui data hubungan antar lembaga Bawaslu RI cenderung memiliki arah untuk membangun hubungan dengan lembaga pemerintah dibanding tiga subjek lainnya seperti NGO, Perguruan Tinggi dan Media.
\end{abstract}

Kata Kunci: Hubungan Antar Lembaga, Pemilu Serentak, Network Governance

\section{PENDAHULUAN}

Pemilu sebagai output dari demokrasi, tidak hanya sebatas dilaksanakan begitu saja tanpa kesiapan dari pemerintah dan masyarakatnya. Melainkan, Pemilu harus menjadikan sistem ketatanegaraan di Indonesia untuk menuju nilai demokratis. Hal ini dikarenakan sudah menjadi tanggung jawab pemerintah sebagai penyelenggara negara untuk menciptakan Pemilu yang demokratis.

Dalam menciptakan Pemilu yang sehat dan demokratis diperlukan suatu lembaga dalam rangka mejalankan suatu kegiatan dalam penyelenggaraan Pemilu. sesuai dengan pernyataan Gunawan Suswantoro bahwa "Integritas penyelenggara dan proses 
penyelenggaraan pemilu adalah prasyarat pentingg dalam pemilu, agar hasil pemilu mendapat pengakuan dari rakyat maupun kontestan pemilu." (Suswantoro, 2016). Melihat pernyataan tersebut, perlu diwujudkan suatu lembaga independen yang memiliki tugas dan fungsi sebagai panitia utama dalam pelaksana dan pengawas Pemilu. Dengan demikian pemerintah merealisasikan gagasan tersebut dengan merumuskan peraturan dalam bentuk Undangundang Nomor 7 tentang Pemilihan Umum di Indonesia yang diundangkan pada tahun 2017.

Pada Undang-undang Nomor 7 Tahun 2017 Tentang Pemilihan Umum, ada tiga lembaga penyelenggara Pemilu yang menjadi satu kesatuan dalam menyelenggarakan Pemilu. Pertama, Komisi Pemilihan Umum yang kemudian disingkat KPU merupakan lembaga dimaana memiliki peran dalam menyelenggarakan kegiatan Pemilu yang dalam pelaksanaannya memiliki sifat nasional, tetap, dan mandiri (UU No 7 Tahun 2017 Tentang Pemilihan Umum). Selanjutnya, Badan Pengawas Pemilihan Umum yang kemudian disingkat Bawaslu. Bawaslu merupakan Lembaga penyelenggara Pemilu dimana memiliki peran dalam perihal pengawasan pada penyelenggaraan Pemilu di Indonesia. Kemudian, Dewan Kehormatan Penyelenggaraa Pemilu yang disingkat DKPP. Lembaga DKPP merupakan lembaga penyelenggara Pemilu yang memiliki peran dalam menangani dan pada pelanggaran kode etik dari para penyelenggara Pemilu. Melihat pemaparan lembaga penyelenggara Pemilu diatas, Bawaslu menjadi lembaga yang memiliki posisi strategis dalam aspek penyelenggaraan Pemilu. Hal ini dikarenakan Bawaslu memiliki kedudukan sebagai lembaga pengawas penyelenggaraan Pemilu.

Dalam segi kelembagaannya, Bawaslu memiliki karakteristik yang unik dimana bisa menunjukan bahwa Bawaslu berbeda dengan kebanyakan lembaga pemerintah lainnya, yaitu eksistensi lembaga dan fungsi lembaga (Suswantoro, 2016). Pertama, dari segi eksistensi lembaga memiliki artian bahwa Bawaslu merupakan satu-satunya lembaga negara di dunia yang memliki tugas dalam melaksanakan pengawasan pada penyelenggaraan Pemilihan Umum.

Kedua, dari segi fungsi kelembagaan Bawaslu memiliki keunikan tersendiri yaitu harus menjalankan tiga fungsi yang umumnya dilakukan oleh lembaga lain secara terpisah. Fungi-fungsi yang harus dijalankan tersebut meliputi: (1) fungsi legislasi, dimana Bawaslu harus mampu menyusun dan memproduksi suatu peraturan yang akan diberlakukan baik secara internal maupun eksternal kelembagannya; (2) fungsi eksekutif, dimana Bawaslu harus menjalankan praktik pengawasan dalam baik dalam bentuk pencegahan maupun penindaklanjutan; dan (3) fungsi yudikatif, dimana Bawaslu memiliki kewenangan untuk melakukan tindakan yang mendekati dalam aspek yudikatif, seperti penyelesaian 
sengketa.(Suswantoro, 2016) Dengan demikian Bawaslu memiliki posisi penting dalam komposisi kelembagaan di Indonesia khususnya dalam ruang lingkup kepemiluan.

Pemilihan Umum di Indonesia memiliki cakupan yang sangat luas baik dari tahap formulasi hingga evaluasi. Pada penyelenggaraan Pemilihan Umum Bawaslu perlu mengawasi segala tahapan dan rangkaian Pemilu yang diselenggarakan di setiap tingkatan dari pusat hingga ke daerah. Pada tahap pengawasan tersebut, didalamnya terdapat tugas Bawaslu untuk melakukan pencegahan dan penindakan atas terjadinya pelanggaran Pemilu bagi pada peserta Pemilu, maupun penyelenggara Pemilu yang dalam hal ini adalah mengawasi KPU. Bawaslu juga akan berkutat dengan urusan Daftar Pemilih, peserta Pemilu, dana kampanye, logistik, pemungutan suara, dan rekapitulasi suara. Selain itu, Bawaslu juga perlu melakukan upaya pencegahan pada praktik politik uang yang menjadi fenomena setiap diadakannya pesta demokrasi tersebut. Bawaslu juga tidak boleh luput dan lalai untuk mengawasi netralitas Aparatur Sipil Negara, Tentara Nasional Indonesia, dan Kepolisian Republik Indonesia.

Melihat hal tersebut, menjadi tantangan tersendiri yang cukup berat untuk dipikul bagi Bawaslu dalam melakukan pengawasan penyelenggaran Pemilu yang memiliki ruang lingkup luas baik dari aspek geografis maupun penyelenggaraanya. Di sisi lain, Bawaslu juga memiliki keterbatasan wewenang yang menjadi kendala dalam memaksimalkan fungsi pengawasan hal ini dibuktikan dari Undang-undang Nomor 7 Tahun 2017 Tentang Pemilihan Umum pasal 95 yang berisi tentang kewenangan bawaslu hanya sebatas memeriksa dan mengkaji serta memberikan rekomendasi terkait pelanggaran dalam ranah kepemiluan (Suswantoro, 2016) padahal ruang lingkupnya akan memasuki beberapa aspek meliputi aspek di luar kepemiluan seperti kependudukan, keamanan, kesehatan, Hak Asasi Manusia, peningkatan sumber daya manusia baik eksternal maupun internal, hukum, penyiaran, informasi, dan pelayanan publik yang notabene segala informasi dan akses berada di luar kewenangan Bawaslu.

Dalam mengatasi kendala keterbatasan wewenang tersebut, Bawaslu bisa menggunakan amanah undang-undang nomor 7 Tahun 2017 yang menjadi payung hukumnya yang telah memfasilitasi Bawaslu untuk memaksimalkan fungsi pengawasannya yakni melakukan hubungan, koordinasi, atau kerja sama antar lembaga terkait. Selain karena situasi hukum tersebut, menjadi peluang juga bagi Bawaslu untuk mengoptimalkan fungsi pengawasannya melalui hubungan antar lembaga dengan lembaga terkait baik itu Government Organization maupun Non Government Organization. 
Urgensi Bawaslu RI dalam menjalin hubungan antar lembaga yakni permasalahan yang kompleks dalam ranah kepemiluan menjadi dasar utama untuk melibatkan para Stakeholder lain untuk ikut andil dalam mengawasi jalannya pemilu. Permasalahanpermasalahan yang ada di kepemiluan dapat dilihat berdasarkan data Bawaslu RI berikut:

\section{Diagram 1}

\section{Data Jenis Pelanggaran Pemilu Berdasarkan Temuan dan Laporan 2019}

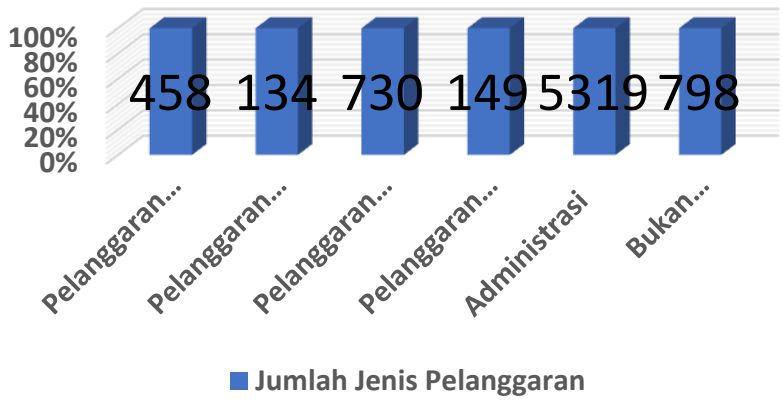

Sumber: Data Pelanggaran Pemilu Tahun 2019, Bawaslu RI

Diagram 2

Data Macam Pelanggaran Pidana Berdasarkan Temuan dan Laporan hingga Tanggal 20 Mei 2019

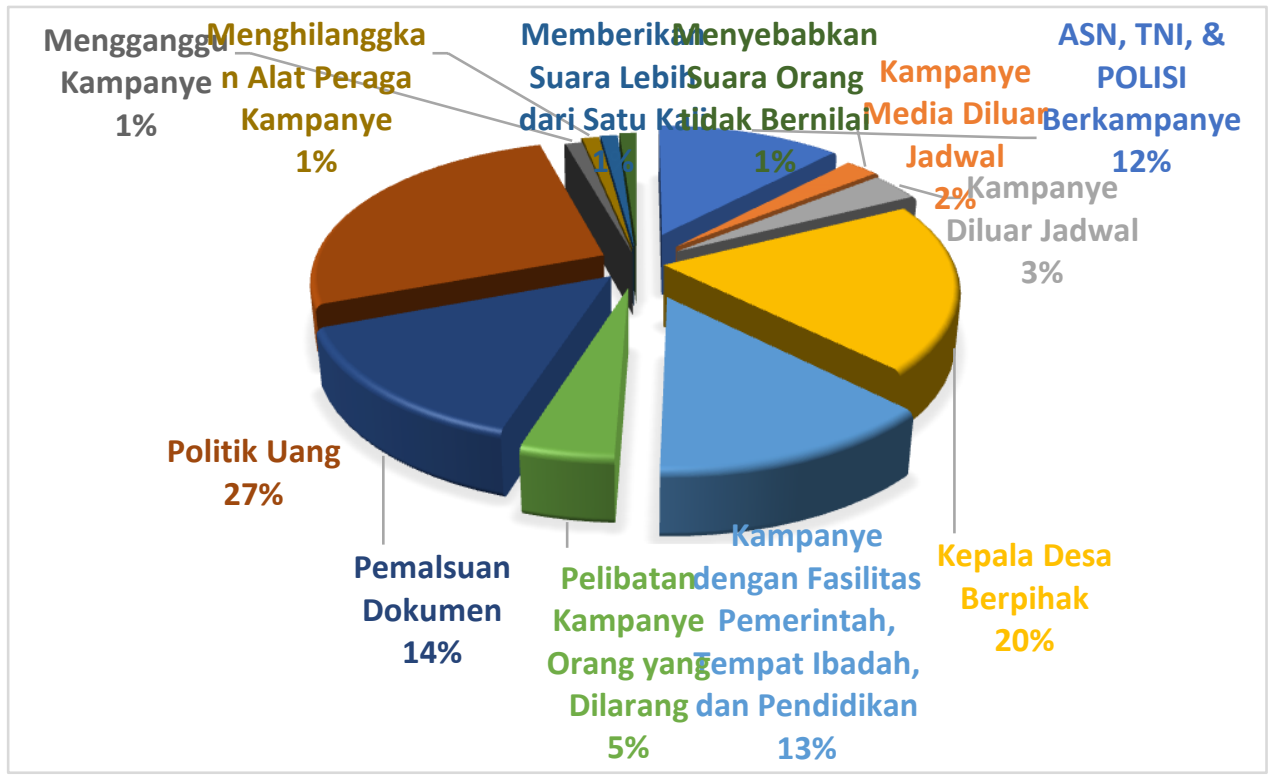

Sumber: Data Pelanggaran Pemilu Tahun 2019, Bawaslu RI

Melihat data yang telah dipaparkan diatas, dapat dipahami bahwa dalam kepemiluan memiliki permasalahan yang kompleks terutama dalam ranah pengawasan Bawaslu RI. Bawaslu RI memiliki beragam permasalahan yang kompleks melalui temuan dan laporan yang didapatkannya. Dengan demikian dibutuhkan keterlibatan Stakeholder lain untuk membantu fungsi pegawasan Bawaslu RI dalam mencegah dan menindak permasalahan yang kompleks tersebut. 
Kelahiran dari konsep yang dikenal dengan Network Governance bermula dari berkembang pesatnya teori tentang Tata Kepemerintahan atau yang biasa dikenal dengan teori Governance. Munculnya teori tentang Network Governance merupakan akibat dari adanya perkembangan demokrasi liberal. Kemudian, perkembangan dari demokrasi liberal juga tidak dapat dipungkiri bahwa telah menyebabkan suatu konsep kesetaraan dalam proses dijalankannya kepemerintahan. Pada perkembangan tersebut melahirkan pemahaman bahwa setiap aktor, institusi, atau lembaga memiliki "Role" yang sama dalam rangka mengelola suatu "Public Interest". Dengan demikian setiap aktor, institusi, atau lembaga akan memposisikan mereka sedemikian rupa hingga berada pada posisi yang bersifat horizontal, sederajat, dan setara dalam rangka pengentasan suatu masalah bersama atau Public Affairs (Sorensen, 2002).

Network sendiri memiliki definisi yaitu Pola hubungan sosial yang stabil antara aktor, institusi, atau lembaga yang saling memiliki ketergantungan pada area masalah kebijakan atau kelompok sumber daya yang meliputi membentuk, memelihara, mengarahkan atau menjaga, dan mengubah suatu situasi melalui serangkaian langkah atau peristiwa. Melihat definisi tersebut dapat dipahami bahwa Network merupakan suatu resiprokal atau yang biasa disebut hubungan timbal balik. Hubungan tersebut terjadi diantara berbagai aktor, institusi, atau lembaga negara yang dalam hal ini sebagai Stakeholders yang terlibat dalam suatu serangkaian pada proses pengambilan suatu keputusan (Yudiatmaja, Safitri, \& Manalu, 2017).

Kemudian, Network sendiri lebih menekankan pada struktur organisasi atau lembaga yang lebih longgar dan terdapat "Trust" atau kepercayaan dalam hubungan antar lembaga tersebut (Haynes, 2003). Hal ini memunculkan perspektif Network sebagai suatu relasi antar lembaga sebagai Stakeholders bersifat lentur dan tidak mengikat secara keseluruhan sehingga konsekuensinya adalah setiap lembaga yang terikat baik secara permanen maupun tidak dalam proses kerja sama tersebut, harus memiliki kepercayaan antar lembaga untuk dijadikan sebagai pondasi dalam melakukan suatu proses kerja sama.

Selanjutnya, Network Governance lahir sebagai akibat atas kompleksitas dalam suatu proses pengambilan keputusan dan implementasinya. Permasalahan yang berkembang semakin kompleks menimbulkan pengambilan keputusan dan implemenrasinya menjadi kompleks pula. Oleh karena itu, situasi tersebut menimbulkan terbukanya peluang atas munculnya pilihan atau alternatif sebagai langkah dalam mengatasi masalah tersebut, sehingga atas dasar tersebut menjadi penyebab harus diadakannya keterlibatan dari berbagai Stakeholders yang dalam hal ini adalah aktor, institusi atau lembaga baik dalam proses 
formulasi maupun dalam proses implementasi suatu kerja sama atau kesepakatan (Klijn \& Koppenjan, 2000).

Kemudian, dalam mengelola kepentingan bersama melalui proses kerja sama, di dalamnya terdapat beraneka aktor atau institusi yang terlibat sesuai dengan kepentingan masing masing yang beragam. Hubungan antar aktor atau institusi dalam proses kerjasama tersebut memiliki sifat saling ketergantungan satu sama lain (Interdependence). Dalam pemahaman tersebut dapat dilihat bahwa setiap aktor atau institusi akan berusaha mencapai pencapaian atau tujuan yang telah ditetapkan masing masing dengan cara memanfaatkan sumber daya atau Resources yang dimiliki oleh institusi yang terlibat dalam jaringannya. Interdependence ini dapat terbentuk melalui proses pertukaran sumber daya antar lembaga, seperti halnya sumber daya finansial, akses, politik, dan informasi.

Network Governance biasanya lebih mengacu pada keterlibatan aktor atau institusi yang bersifat non-state dalam menjalankan kepemerintahan. Pelibatan institusi tersebut dapat ditemukan melalui hubungan dan tata kerja sama antar institusi di dalam jaringan. Keterlibatan institusi atau lembaga dalam menjalankan jejaring kepemerintahan perlu ada manajemen atau tata kelola yang baik dalam rangka mengelola kepentingan dan masalah bersama lebih efektif. Oleh karena itu, dalam menjalankan Network Governance ada dua indikator yang harus diimplementasikan, yaitu (Klijn, Koppenjan, \& Termeer, 1995)

1. Game Management, yaitu serangkaian langkah strategis yang berkelanjutan antar instansi atau lembaga yang diatur atau disusun sedemikian rupa berdasarkan persepsi antar lembaga melalui aturan formal dan informal yang ada mengenai isu permasalahan yang telah menjadi kepentingan, atau perhatian bagi para lembaga. Game Manegement ini memiliki tujuan utama yaitu menyatukan berbagai persespsi yang dimiliki oleh lembaga yang terlibat dengan cara membentuk suatu norma yang bersifat normal dan informal yang kemudian nantinya akan mengembangkan suatu keputusan yang menjadi kepentingan bersama. Dalam Game Management, terdapat tiga elemen yakni:

a. Persepsi/Interpretasi

Persepsi yang diterapkan dalam Game Management adalah Convenanting atau Pertemuan. Pada pertemuan tersebut akan melakukan eksplorasi tentang persamaan dan perbedaan pada persepsi yan dimiliki antar lembaga. Kemudian, dilakukan penjajakan sebagai bentuk upaya dalam menyatukan dan menyelaraskan tujuan bersama.

b. Aktor/Sumber Daya 
Secara Selective Activation akan dilakukan mobilisasi kekuatan atau potensi yang dimiliki oleh masing-masing lembaga sesuai dengan kepentingan bersama yang telah ditetapkan sebelumnya. Dalam hal ini akan memobilisasi lembaga yang memiliki sumber daya yang kurang dan mendemobilisasi lembaga yang mendominasi sumber daya.

c. Institusi/Norma

Dalam jaringan ini akan dilakukan Arranging atau pembentukan norma yang akan dijaga secara bersama dengan pondasi kepercayaan yang dimiliki oleh masing-masing lembaga sehingga selanjutnya akan mengubah format relasi yang mendorong pada lahirnya interaksi dalam kelompok.

2. Network Structuring, yaitu upaya dalam rangka melakukan transformasi terhadap struktur jaringan. Tata kelola ini memiliki asumsi bahwa karakteristik institusional jaringan dapat mempengaruhi strategi dan peluang pada kerja sama antar lembaga tersebut. kemudian upaya dalam rangka mengubah jaringan dapat dilakukan melalui perubahan satu atau lebih karakter institusional tersebut dari masing masing lembaga. Network Structuring mencoba untk melakukan perubahan secara struktural atas kelembagaan antar institusi atau lembaga. Hal ini bertujuan untuk memberi akses dan ruang serta memberikan fasilitas dalam implementasi kerja sama dalam jaringan tersebut. Network Structuring ini dalam implemenasinya memiliki tiga elemen yakni:

a. Persepsi/Interpretasi

Persepsi yang terdapat dalam Network Structuring yaitu Reframing.Reframing dilakukan dengan cara melakukan perubahan pada persepsi dari peran suatu lembaga dalam jaringan tersebut yang akan dilakukan pembentukan kerangka dalam menentukan suatu nilai yang akan diperjuangkan sehingga dalam hal ini akan dilakukan semacam peleburan tujuan dari masing-masing lembaga.

b. Aktor/Sumber Daya

Secara Network Activation akan dilakukan pelibatan para lembaga-lembaga baru atau merombak guna mengubah posisi dari lembaga atau institusi yang telah ada serta tidak menutup kemungkinan akan melahirkan koalisi baru.

c. Institusi/Norma

Dalam agenda ini akan dilakukan Reconstitutionalism, yaitu dilakukannya perubahan kebijakan, norma atau aturan, dan sumber daya di dalam jaringan secara fundamental. 


\section{PEMBAHASAN}

\section{Jejaring Kelembagaan dalam Penangan Pelanggaran Pemilu}

Berdasarkan konsep Network Governance oleh Klijn, Koppenjan, \& Termeer terdapat srategi dalam menjalankan fungsi lembaga untuk mencapai suatu tujuan tertentu dapat diimplementasikan melalui dua strategi yaitu Game Management dan Network Structuring (Klijn, Koppenjan, \& Termeer, 1995). Dalam Upaya Bawaslu dalam melakukan pencegahan pelanggaran pemilu serentak 2019, Bawaslu RI membangun serta menjalankan konsep Network Governance atau jaringan dalam tata kepemerintahan. Hal ini dapat dilihat melalui langkah yang diambil dalam menyelenggaraakan pencegahan pelanggaran pemilu tersebut, salah satunya melalui hubungan antar lembaga yang melibatkan beberapa aktor atau institusi meliputi Lembaga Pemerintah, Non Government Organization, Perguruan Tinggi, dan Media.

Sesuai dengan konsep Klijn, Koppenjan, \& Termeer, dasar Bawaslu RI menggandeng beberapa institusi disebabkan oleh kompleksitas permasalahan yang ada, Kompleksitas permasalahan Bawaslu RI dapat dilihat melalui temuannya yang terdapat 7.598 temuan dan laporan pelanggaran yang didalamnya dapat diklasifikasi berdasarkan kategori seperti 458 pelanggaran pidana, 134 pelanggaran dalam proses, 730 pelanggaran hukum, 149 pelanggaran kode etik, 5.139 pelanggaran administrasi, dan 798 ditentukan sebagai bukan pelanggaran. Sehingga, dibutuhkan keterlibatan dari berbagai Stakeholders baik dalam tahap formulasi, implementasi, hingga evaluasi.

Melalui hubungan antar lembaga, Bawaslu RI mengimplementasikannya melalui dua strategi tersebut, antara lain: melalui stategi Game Management, Bawaslu RI memiliki serangkaian langkah strategis yang bersifat berkelanjutan antar lembaga yang telah diatur dan disusun sedemikian rupa melalui kerja sama. Kerja sama ini disusun sedemikian rupa sehingga terbentuk sebuah naskah yang bernama Nota Kesepahaman. Kerja sama ini dibentuk berdaasarkan persepsi masing-masing lembaga yang tertuang dalam aturan formal dan informal mengenai isu permasalahan yang telah menjadi kepentingan bersama terebut. Bawaslu menjalankan langkah strategis yang bersifat berkelanjutan ini juga didasarkan oleh tiga permasalahan utama yang selalu lahir dari tahun ke tahun yaitu Netralitas Aparatus Sipil Negara, Kependudukan, dan Kampanye di Media. Dengan demikian, Bawaslu menggandeng lembaga pemerintah terkait untuk menangani permasalahan tersebut seperti TNI, POLRI, KASN, Ditjen Dukcapil, dan KPI.

Selain dengan lembaga pemerintah, Bawaslu RI juga menggandeng Non Government Organization, perguruan tinggi, dan media untuk berpartisipasi bersama-sama mengawasi penyelenggaraan Pemilu. Dimana hubungan antar lembaga ini dilaksanakan dalam bentuk 
Forum Group Discussion. FGD ini diikuti oleh ketiga institusi tersebut dalam rangka meminta kritik, masukan, evaluasi, dan sebagainya dalam perspektif ideologi dan peran masing masing dalam hal ini sesuai perspektif Lembaga masyarakat dan perguruan tinggi tersebut (wawancara dengan Ali Imron Bawaslu RI, 2019)

Sementara itu, Media dalam hal ini Hukumonline akan meliput segala bentuk kegiatan penyelenggaraan pengawasan Pemilu untuk dipublikasi ke masyarakat. Kegiatan tersebut setiap momen Pemilu akan dilaksanakan. Selain untuk evaluasi, hubungan tersebut juga diperlukan untuk menjaga pola hubunga stabil dan sebagai langkah strategis berkelanjutan. Jadi, Bawaslu RI membutuhkan perspektif mereka untuk melakukan evaluasi dan memahami apa saja yang kurang dalam di dalam sebuah penyelenggaraan Pemilu kemarin. Hal ini juga perlu dilakukan mengingat bahwa tidak mungkin evaluasi dan kritik berasal dari lingkungan internal Bawaslu RI, melainkan harus melibatkan dari eksternal pula, sehingga menjadikan pola hubungan yang stabil tetap terjaga.

Selanjutnya, dalam melakukan tata kelola Network Governance melalui Game Manegement, terdapat tiga langkah dalam mengimplementasikan atau menjalankan tata kelola pada Network Goverance, yaitu membentuk Persepsi/Interpretasi, menentukan Aktor/Sumberdaya, dan membangun Institusi/Norma. Dalam pencegahan pelanggaran pemilu, Bawaslu RI menciptakan dan mengelola hubungan antra lembaga berdasarkan tiga langkah tersebut, antara lain:

a. Membentuk Persepsi/Interpretasi

Sebuah hubungan antar lembaga yang dilakukan oleh Bawaslu RI secara sederhana dapat dihat melalui tiga tahap yaitu Formulasi, Implementasi, dan Evaluasi (wawamcara dengan Ali Imron Bawaslu RI, 2019) Pada tahap formulasi inilah terjadi pembentukan persepsi pada masing-masing lembaga. jadi, pada awalnya biasanya Bawaslu RI terlebih dahulu berinisiatif untuk menyusun konsep gambaran scara mentah dan makro terkait agenda lembaga apa yang akan dilakukan sebuah kerja sama. Konsep tersebut disusun oleh Tenaga Ahli yang berkoordinasi dengan Koordinator Divisi terkait atau bisa langsung ditentukan lembaganya oleh Komisoner Bawaslu RI karena sudah berkoordinasi secara informal dengan pimpinan di lembaga terkait.

Setelah konsep tersusun, Bawaslu mengundang lembaga terkait untuk dilakukan sebuah pertemuan dalam satu ruangan untuk menawarkan gagasan dan konsep kerja sama yang telah disusun oleh Bawaslu di dalam pertemuan yang disebut Audiensi. Audiensi ini menjelaskan maksud kedatangan dan 
menginformasikan bahwa akan ditindaklanjuti dalam bentuk kerja sama kedepan. Audiensi ini berfungsi untuk melakukan sosialsasi dan memberikan pemahaman bahwa perlu untuk lembaga tersebut melakukan kerja sama. Jadi, lembaga terkait juga merasa dibutuhkan dan muncul rasa tanggung jawab sebagai lembaga negara ataupun lembaga swadaya masyarakat.

Pada forum tersebutlah kemudian terjadi pembentukan persepsi antar lembaga. Jadi, Bawaslu membentuk persepsi dengan cara menyamakan kepentingan dari masing-masing lembaga yang bisa dileburkan atau disamakan pada suatu isu permasalahan. Pembentukan persepsi ini dilakukan dengan memberikan sosialisasi berupa pemahaman bahwa ada urgensi dan telah menjadi kepentingan bersama untuk diadakan sebuah kerja sama. Misalnya dalam masalah Kampanye di media penyiaran telah menjadi kebutuhan bersama bagi Bawaslu dan KPI untuk bekerja sama karena KPI memiliki ranah dalam mengawasi penyiaran sedangkan Bawaslu memiliki ranah dalam mengawasi kampanye peserta pemilu, sehingga untuk menangani permasalahan kampanye yang dilakkan di media penyiaran maka menjadi urgensi dan kepentingan bersama bahwa KPI dan Bawaslu untuk melakukan kerja sama. Dengan demikian melalui kegiatan tersebut pembentukan persepsi telah dilakukan sebagai langkah awal oleh Bawaslu RI.

b. Menentukan Aktor/Sumberdaya

Dalam menentukan sebuah pihak atau lembaga yang akan dilakukan kerja sama, Bawaslu bisa menentukan suatu lembaga dengan melihat dari potensi yang dimiliki oleh suatu lembaga. Aktor atau lembaga yang berpotensi dilakukan kerja sama dilihat melalui tiga aspek yaitu Akses, Informasi, dan Data. Ketiga aspek tersebut menjadi poin utama dalam menentukan dengan siapa akan dilakukan sebuah kerja sama. Pertama, Akses yang dimiliki oleh suatu lembaga harus luas dalam suatu ranah tertentu untuk mempermudah kerja lembaga Bawaslu RI. Akses yang luas bisa digunakan oleh Bawaslu sebgai sumber daya untuk melakukan, mengelola, dan mendapatkan sesuatu karena melihat keterbatasan wewenang yang dimiliki oleh Bawaslu RI. Kedua, Informasi yang bisa dimiliki atau dihimpun oleh suatu lembaga harus memiliki nilai kegunaan yang bermanfaat untuk bisa digunakan oleh Bawaslu RI sehingga informasi dapat diolah dengan baik untuk keperluan pengawaan pemilu. Ketiga, Data yang dimiliki oleh suatu lembaga harus memiliki kekuatan yang tidak diragukan atau valid yang disebabkan oleh dampak undang-undang ataupun kredibilitas lembaga itu sendiri. 
Salah satu lembaga yang telah ditentukan untuk bekerjasama secara berkelanjutan oleh Bawaslu RI yaitu Kementerian Dalam Negeri. Kementerian Dalam Negeri penting untuk digandeng dalam pengawasan pemilu karena Kemendagri memiliki akses, informasi, dan data yang luas dan valid terkait kependudukan. Dengan demikian, melalui potensi-potensi tersebut Bawaslu menentukan aktor atau pihak kerja sama berdasarkan sumber daya yang dimilikinya yang kemudian akan dilakukan pertemuan pada forum yang disebut Forum Koordinasi Awal.

c. Membangun Institusi/Norma

Setelah konsep mentah disusun oleh Bawaslu, maka akan dilakukan Forum Koordinasi Awal yang akan dijadikan wadah untuk membangun sebuah norma. Pada forum ini Bawaslu RI akan mengundang lembaga terkait yang telah ditentukan. Pertemuan ini akan membahas dan menyusun draft tentang bagaimana gagasan dan konsep kerja sama akan dilakukan.

Setelah itu, dilakukan Forum Koordinasi Lanjutan dimana draft yang telah didiskusikan sebelumnya dilakukan perbaikan sesuai dengan kepentingan masingmasing lembaga lalu diserahkan draft tersebut ke lembaga terkait untuk dibahas dan dikaji oleh internal kelembagaan tersebut. kemudian, akan dilakukan Forum Koordinasi Lanjutan selanjutnya untuk menyikronkan antar kepentingan lembaga dan seterusnya hingga mencapai tahap sepakat atau Deal.

Para pihak membentuk suatu naskah kerja sama yang akan disepakati bersama disebut dengan naskah Nota Kesepahaman sehingga di situlah sebuah pembentukan norma terjadi. Nota Kesepahaman ini akan diisi terkait maksud dan tujuan kerja sama, dan substansi yang dikerjasamakan apa saja, serta aturan aturan yang harus dipatuhi sebagai bentuk konsekuensi dari sebuah kesepahaman sehingga pada tahap ini sebuah norma telah dibangun untuk ditaati bersama. Isi dari nota kesepahaman sekaligus menjadi norma yang bersifat formal karena tertera di dalam sebuah naskah, sementara itu sebuah hubungan yang telah terjalin melalui nota kesepahaman tersebut akan menjadi hubungan baik antar lembaga sehingga akan membentuk norma-norma tersirat lainnya antar masing-masing lembaga.

Selanjutnya, melalui strategi Network Structiring, Bawaslu RI telah melakukan upaya dalam rangka melakukan transformasi terhadap struktur jaringan sebagai manifestasi pada sebuah hubungan antar lembaga. Transformasi atau perubahan pada struktur jaringan ini 
bertujuan untuk memberikan akses, ruang, dan fasilitas dalam mengimplementasikan kerja sama yang telah disepakati di dalam jaringan tersebut. di Bawaslu RI strategi ini biasanya dilakukan dalam bentuk Perjanjian Kerja Sama.

Dalam melakukan tata kelola Network Governance melalui Network Structuring, terdapat tiga langkah yang sama halnya dengan Game Management dalam mengimplementasikannya. Pada upaya pencegahan pelanggaran pemilu melalui hubungan antar lembaga, Bawaslu membentuk Perjanjian Kerja Sama berdasarkan tiga langkah, sebagai berikut:

a. Membentuk Persepsi/Interpretasi

Dalam membentuk persepsi lebih lanjut, dilakukan Reframing. Reframing dilakukan dengan cara melakukan perubahan pada persepsi dari peran suatu lembaga dalam jaringan tersebut yang kemudian dilakukan pembentukan kerangka dalam menentukan suatu nilai yang akan diperjuangkan sehingga dalam hal ini akan dilakukan semacam peleburan tujuan dari masing-masing lembaga.

Pembentukan Reframing yang dilakukan oleh Bawaslu yakni peleburan tujuan dari masing masing lembaga terkait untuk dijadikan menjadi satu kesatuan sebagai kepentingan yang harus dicapai bersama. Misalnya, antara Bawaslu, Kepolisian, dan Kejaksaan memiliki fungsi yang berbeda satu sama lain. Bawaslu berfungsi sebagai pengawas pemilu, Kepolisian berfungsi sebagai pelindung masyarakat, dan kejaksaan berfungsi untuk menegakkan keadilan. Namun perbedaan tersebut akan dilakukan peleburan sehingga menjadi satu kesatuan fungsi dalam suatu permasalahan tertentu yang dalam hal ini adalah permasalahan pelanggaran pidana pemilu.

Untuk menangani permasalahan pelanggaran pidana pemilu, Bawaslu harus menggandeng kepolisian dan kejaksaan untuk bekerja sama menangani masalah pidana pemilu. hal ini dikarenakan keterbatasan wewenang yang masing masng lembaga miliki. Oleh karena itu melalui kerja sama dapat bersinergi untuk saling bahu membahu dalam menangani masalah pelanggaran pidana pemilu. sehingga Reframing dilakukan dengan mencantumkan dalam undang undang bahwa Bawaslu, Kepolisian, dan Kejaksaan akan bekerja sama menangani pelanggaran pidana pemilu melalui suatu badan yang bernama Sentra Gakkumdu.

b. Menentukan Aktor/Sumberdaya

Pada Network Structuring, penentuan aktor bisa melibatkan aktor baru atau merombak posisi yang sudah ada sehingga melahirkan kelompok atau koalisi baru. 
Dalam hal ini sebagai tindaklanjut dari sebuah Perjanjian Kerja Sama, Bawaslu telah membentuk suatu kelompok kerja baru yang mempengaruhi struktur kelembagaan yang telah ada, yaitu pembentukan Sentra Penegakan Hukum Terpadu atau Sentra Gakkumdu yang beranggotakan Bawaslu RI, Kepolisian, dan Kejaksaan untuk optimalisasi penanganan pidana Pemilu. Selain itu juga ada dibentuk Panitia Pemilihan Luar Negeri (PPLN) sebagai manifestasi kerja sama antara Bawaslu RI dengan Kementerian Luar Negeri untuk memfasilitasi Pemilihan Umum di luar negeri (Bawaslu.go.id, 2019)

Selain membentuk kelompok atau koalisi baru seperti diatas, Bawaslu telah merombak suatu posisi dalam sebuah struktur jaringan dan melibatkan lembaga baru untuk masuk ke dalam jaringan tersebut. Hal ini dapat dilihat melalui kerja sama terkait pengawasan netralitas Aparatur Sipil Negara, TNI, dan Kepolisian. Pada awalnya Bawaslu RI menggandeng enam lembaga sekaligus yaitu Kementerian Pendayagunaan Aparatur milik Negara dan Reformasi Birokrasi, Badan Kepegawaian Negara, Kementerian Dalam Negeri, Komisi Aparatur Sipil Negara, Tentara Nasional Indonesia, dan Kepolisian Negara Republik Indonesia. namun terjadi evaluasi bersama dan berimbas pada perombakan dalammomen Pemilu berikutnya dimana Bawaslu RI hanya menggandeng Komisi Aparatur Sipil Negara, Tentara Nasional Indonesia, dan Kepolisian Negara Republik Indonesia untuk bekerja sama dalam pengawaan netralitas ASN karena menilai bahwa Kemenpanrb, Kemendagri, dan BKN tidak memiliki kepentingan terkait pemberian sanksi dan pengawasan terhadap Aparatur Sipil Negara.

c. Membangun Institusi/Norma

Berdasarkan konsep Network Governance, pada agenda ini akan dilakukan Reconstitutionalism, yakni dilakukannya perubahan kebijakan, norma, aturan, dan sumber daya di dalam jaringan secara fundamental. Setelah terbentuknya sebuah Nota Kesepahaman, biasanya akan ditindaklanjuti dengan membentuk Perjanjian Kerja Sama yang akan lebih bersifat teknis, mendalam, rinci, dan mengikat antar lembaga. di dalam naskah tersebut kemudian terjadi Reconstitutionalism yang didalamnya berisi perubahan dari segi kebijakan, norma, aturan, dan sumber daya pada naskah sebelumnya. Ketentuan yang tergantung dalam naskah Perjanjian Kerja Sama akan lebih rinci dan bersifat bagian teknis sebagai pelaksana dari hasil kerja sama tersebut, sehingga akan dibentuk norma atau aturan baru yang lebih bersifat rinci dan teknis sesuai batasan ruang lingkup kerja sama sehingga sumber 
daya di dalam jaringan juga akna lebih detail dijelaskan sehingga kerja sama akan dilakukan secara konkret oleh masing masing lembaga.

Misalnya, pada sebuah Nota Kesepahaman antara Bawaslu RI dengan TNI, Kepolisian, dan KASN itu berisi tentang pengawasan netralitas anggota TNI, Kepolisian, dan KASN, serta penyebutan tujuan dan ruang lingkup secara makro secara umum bagi lembaga terkait tersebut. sebagai tindaklanjut dari Nota Kesepahaman tersebut makan dibentuk Perjanjian Kerja Sama yang terdiri dari masing masing pihak tersebut. salah satunya Perjanjian Kerja Sama Bawaslu RI dengan TNI. Dari segi kebijakan, norma, aturan, dan sumber daya pada naskah Nota Kesepahaman terjadi perubahan pada Perjanjian Kerja Sama. perubahan tersebut berisfat lebih teknis dan rinci seperti dibentuknya kebijakan dan sumber daya bar yaitu Satuan Tugas (Satgas) yang terdiri dari Bawaslu RI dan TNI. Kemudian, norma dan aturan juga lebih rinci tercantum di dalamnya seperti mengenai hak dan kewajiban masing-masing pihak. Dengan demikian fenomena Reconstitutionalism disitulah terjadi.

\section{Pola Hubungan Antar Lembaga Bawaslu RI dengan Stakeholders}

Dalam melakukan hubungan antar lembaga, penulis mengamati terdapat pola hubungan dalam menjalankan hubungan antar lembaga tersebut sebagai bentuk tata kepemerintahan. Berdasarkan konsep Network Governance, sebuah jaringan di dalamnya terdapat beberapa sifat yaitu kesetaraan, fleksibilitas, dan saling ketergantungan. Berikut beberapa sifat yang dapat ditemui dalam pola hubungan antar lembaga Bawaslu RI dengan Stakeholder, antara lain:

a. Kesetaraan dalam Hubungan Antar Lembaga.

Pada konsep Network Governance, sebuah institusi atau lembaga memiliki pada posisi yang setara, sederajat, atau horizonal dengan lembaga lain dalam menjalankan sebuah jaringan. Pola hubungan yang terjadi dalam hubungan antar lembaga yang dilakukan Bawaslu RI terdapat tingkat kesetaraan antar lembaga atau aktor yang terlibat dalam suatu hubungan tersebut. Hal ini dapat diamati salah satunya melalui hubungan atau kerja sama antar lembaga yang diadakan antar lembaga penyelenggara Pemilu yang dalam hal ini adalah Bawaslu RI dan KPU RI. Didalam sebuah lembaga pastinya terdapat kepentingan dan kewenangan masing masing. Dalam konteks Pemilu, KPU atau Komisi Pemilihan Umum memiliki kepentingan dan kewenangan untuk menggelar setiap tahapan yang disusun untuk menyelenggarakan Pemilu, sementara itu Bawaslu hadir dalam membantu penyelenggaraan Pemilu sebagai lembaga yang mengawasi setiap proses tahapan KPU dalam penyelenggaraan 
tersebut. Selain itu, Komisi Penyiaran Indonesia (KPI) mempunyai kewenangan untuk melaksanakan pengawasan kampanye di media, Dewan Pers mempunyai kewenangan untuk mengawasi segala bentuk pemberitaan terkait kampanye di media cetak, dan Komisi Informasi (KI) pun demikian dalam konteks keterbukaan informasi Pemilu. (wawancara dengan Ali Imron Bawaslu RI, 2019)

Pada konteks ini, sebuah hubungan antar lembaga dibentuk melalui kerja sama dengan menyesuaikannya dengan kewajiban masing-masing dikarenakan setiap lembaga memiliki suatu kewenangan yang tidak dimiliki oleh lembaga lain. misalnya terjadi suatu pelanggaran kampanye di suatu media penyiaran, KPI tidak bisa memberikan sanksi kepada peserta Pemilu yang melakukan pelanggaran di media tersebut, oleh karena itu diadakan kerja sama Bawaslu untuk mewujudkan kepentingan masing-masing dalam menjalankan fungsi lembaganya. Melalui hubungan yang terjalin tersebut, Bawaslu bisa memberikan sanksi kepada peserta Pemilu yang melanggar kampanye di media tersebut, dan KPI bisa memberikan sanksi kepada media yang menjadi platform dari peserta Pemilu tersebut.

Sama halnya dengan pola hubungan antar lembaga yang dibangun oleh Bawaslu RI dengan elemen masyarakat, media, dan perguruan tinggi. Bawaslu tidak memiliki kewenangan, cakupan, dan sumber daya yang dimiliki oleh masyarakat, media, dan perguruan tinggi. Mesikipun memiliki tanggung jawab untuk melaksanakna pengawasan di seluruh wilayan NKRI, Bawaslu RI tidak memiliki cakupan yang luas ke beberapa daerah untuk melakukan pengawasan Pemilu sehingga, dibutuhkan kerja sama dengan masyarakatmelalui Non Government Organization untuk membantu dalam pemantauan setiap rangkaian proses Pemilu. lalu, paada aspek perguruan tinggi Bawaslu RI tidak memiliki sdm yang tinggi untuk membantu peningkatan kapasitas dalam urusan pengawasan Pemilu. kemudian, media memiliki peran yang vital sebagai jembatan antara Bawaslu RI dengan masyarakat. Dengan demikian, setiap subjek yang diajak kerja sama oleh Bawaslu RI akan menerapkan pola hubungan yang setara atau horizontal pada setiap lembaga yang terlibat.Sehingga, melalui kerja sama yang yang dibangun akan timbul kesetaraan dalam melaksanakannya.

Jadi, setiap lembaga memiliki keterbatasan wewenang dalam menjalankan fungsinya. Sekaligus menjadi upaya wujud penghormatan kepada institusi lain apabila diajak untuk melakukan kerja sama. Sehingga, disitulah suatu kesetaraan terjadi. Pola hubungan yang berlandaskan kesetaraan dan kesederajatan ini lahir akibat dari konsekuensi wewenang yang terbatas, jadi, dapat dikatakan bahwa dalam melaksanakan suatu hubungan antar lembaga tidak ada yang merasa superior atau lebih tinggi dibandingkan lembaga lain. 
b. Fleksibilitas dalam Hubungan Antar Lembaga

Selain kesetaraan, konsep Network Governance juga memiliki sifat yang fleksibel dalam menjalankan hubungan antar lembaga. Dalam hal ini, hubungan antar lembaga yang dilakukan oleh Bawaslu RI dapat dibedakan berdasarkan prioritas isu permasalahannya sehingga ada hubungan yang bersifat fleksibel, lentur, dan longgar atau ada yang bersifat kaku, formal, dan tidak fleksibel. Untuk hubungan yang bersifat fleksibel itu biasanya Bawaslu RI melakukan hubungannya dengan Non Government Organization, perguruan tinggi, dan Media. Hal ini sesuai dengan tujuan diadakannya sebuah hubungan antar lembaga yaitu dilakukan bukan untuk menciptakan ketegangan melainkan untuk mempermudah koordinasi dan pelaksanaan kewenanngan masing-masing lembaga. Konsekuensi dari hubungan yang longgar ini pun sering dirasakan misalnya dalam hal pengawasan apabila lembaga terkait tidak melaksanakan manifestasi dari kesepakatan pun tidak menjadi masalah, jadi tidak ada kewajiban dari lembaga terkait untuk melaporkan hasil pengawasannya secara rutin, jadi bisa dikatakan setiap pihak dalam hal ini memiliki komitmen dan kepercayaan satu sama lain untuk menjalankan sebuah kerja sama.

Sementara itu, biasanya Bawaslu RI lebih tegang atau kaku dalam melakukan hubungan antar lembaga dengan lembaga pemerintah terutama yang didalamnya terdapat isu permasalahan yang cukup kompleks dan memiliki konsekuensi hukum. Misalnya dengan Komnas HAM dimana ada suatu pelanggaran terkait Hak Asasi Manusia dalam Pemilu, maka Bawaslu RI bersama Komnas HAM harus bersinergi menangani permasalahan tersebut sesuai kesepakatan di Nota Kesepahaman ataupun Perjanjian Kerja Sama yang telah disusun bersama.

c. Saling ketergantungan/Interdependence dalam Hubungan Antar Lembaga

Selanjutnya, pada Network Governance tidak hanya ditemukan hubungan yang setara dan fleksibel, melainkan terdapat sifat saling ketergantungan antar lembaga dalam menjalankan hubungan dengan lembaga lain yang didalamnya terdapat ketergantungan sumber daya finansial, akses, politk, dan informasi. Hubungan antar lembaga antara Bawaslu RI dengan para Stakeholder melahirkan interdependence atau salingketergantungan. Ketergantungan ini lahir didasari oleh Keterbatasan Wewenang yang dimiliki oleh setiap lembaga baik itu lmebaga pemerintah maupun non pemerintah.

Ketergantungan dalam sebuah jaringan tata kepemerintahan memiliki empat indikator yaitu Sumber Daya Finansial, Akses, Politik, dan Informasi. Dari keempat indikator tersebut, Bawaslu RI hanya memiliki ketergantungan dalam aspek sumber daya Akses, Politik, dan Informasi. Dalam aspek sumber daya finansial, Bawaslu RI tidak mengalami ketergantungan 
dalam aspek finansal karena segal bentuk kegiatan yang diselenggarakan oleh Bawaslu RI dibiyai oleh APBN.

Kemudian, dalam aspek sumber daya akses Bawaslu RI memiliki ketergantungan. Hal ini dapat dilihat melalui tugas Bawaslu untuk mengawasi terkait DPT yang ditetapkan oleh KPU, namun tidak memiliki kewenangan untuk mendapatkan akses mengenai kependudukan, karena hal itu menjadi ranahnya Kementerian Dalam Negeri, sehingga Bawaslu RI harus menggandeng Kementerian Dalam Negeri untuk mendapatkan akses kependudukan. Kerja sama dengan media yang dalam hal ini adalah media Hukumonline.com menjadikan ketergantungan akses bagi Bawaslu dikarenakan Bawaslu perlu sebuah platform media yang bersifat aksesibel bagi setiap kelompok masyarakat guna mempublikasi informasi yang berkaitan denga penyelenggaraan pengawasan Pemilu.

Selain itu, Bawaslu RI juga memiliki ketergantungan sumber daya politik. hal ini bisa dilihat melalui keterbatasan wewenang yang dimiliki Bawaslu, sehingga Bawaslu perlu menjaga hubungan baik dengan lembaga pemerintah dan non pemerintah lainnya guna mendapatkan dukungan dalam hal mengawasi penyelenggaraan Pemilu. sehingga memudahkan koordinasi dalam pelaksanaan masing masing wewenang lembaga terkait.

Kemudian, dalam aspek sumber daya informasi Bawaslu RI merasa jadi ketergantungan untuk melakukan kerja sama dengan sebuah lembaga yang memiliki informasi penting terkait mengawasi penyelenggaraan Pemilu. Misalnya kurangnya Sumber Daya Manusia yang dimiliki oleh Bawaslu RI menjadikan harus melakukan kerja sama dengan perguruan tinggi baik dalam hal pengawasan partisipatif maupun peningkatan SDM. Tidak hanya perguruan tinggi, Bawaslu RI juga perlu mendapatkan informasi yang dimiliki oleh masing masing lembaga pemantau yang dalam hal ini adalah Non Government Organization karena Bawaslu RI juga tidak bisa menjangkau keseluruhan wilayah NKRI hingga ke bagian dipelosok.

\section{KESIMPULAN}

Melihat pemaparan diatas dapat disimpulkan bahwa Dalam melakukan pencegahan pelanggaran pemilu, Bawaslu RI sebagai lembaga pengawasan mengambil langkah salah satunya melalui hubungan antar lembaga. Bawaslu RI telah melakukan hubungan antar lembaga dengan beberapa lembaga baik itu pemerintah, swasta, ataupun masyarakat yang dapat diklasifikasi menjadi empat pihak yaitu Lembaga Pemerintah, Non Government Organization, Perguruan Tinggi, dan Media. 
Selanjutnya, dalam melaksanakan hubungan antar lembaga, Bawaslu RI mematenkannya melalui suatu tata naskah yang dijadikan wadah bersama sebagai komitmen dalam melakukan hubungan antar lembaga. tata naskah tersebut terdiri dari dua jenis yaitu tata naskah Nota Kesepahaman dan Perjanjian Kerja Sama. Komitmen dan keinginan yang kuat dari setiap pihak akan difasilitasi melalui tata naskah tersebut sebagai wujud nyata dalam melakukan kerja sama sehingga kedepannya akan melahirkan output dari hubungan antar lembaga tersebut yang masing masing berbeda tergantung substansi yang ada di dalamnya.

Dalam menjalankan hubungan antar lembaga tersebut telah diimplementasikan beberapa indikator Network Governance sehingga dapat dilihat bagaimana jejaring kelembagaan dijalankan pada hubungan antar lembaga Bawaslu RI dengan Stakeholders.Kemudian, melalui data hubungan antar lembaga Bawaslu RI cenderung memiliki arah untuk membangun hubungan dengan lembaga pemerintah

Kemudian, dapat disimpulkan bahwa terdapat arah hubungan antar lembaga yang dilakukan oleh Bawaslu RI yakni cenderung ke arah lembaga pemerintah. berdasarkan analisis dari dokumen tersebut maka bisa didapati bahwa dalam membangun hubungan antar lembaga Bawaslu RI cenderung lebih mengarah ke lembaga pemerintah sebagai partner dalam mayoritas kerja samanya dibanding perguruan tinggi, NGO, dan media. Hal ini dilatarbelakangi oleh keterbatasan wewenang yang dimiliki oleh lembaga negara di Indonesia.

\section{DAFTAR PUSTAKA}

\section{Buku}

Haynes, P. 2003. Managing Complexity in the Public Services. Berkshire: Open University Press.

Suswantoro, G. 2016. Mengawal Penegak Demokrasi Di Balik Tata Kelola Bawaslu \& DKPP. Jakarta: Erlangga.

Gunawan Suswantoro, Mengawal Penegak Demokrasi Di Balik Tata Kelola Bawaslu \& DKPP, 2016, Jakarta: Erlangga,

\section{Jurnal}

E-H. Klijn \& J. Koppenjan, Public Management and Policy Networks: Foundations of a Network Approach to Governance, Journal Public Management Volume 2 No. 22000 hlm 135-158 diakses melalui http://proceeding.unisba.ac.id/index.php/sosial/article/download/1229/pdf 
Klijn, E.-H., \& Koppenjan, J. 2000. Public Management and Policy Networks: Foundations of a Network Approach to Governance. Journal Public Management Volume 2 No. 2 , 135-158.

Sorensen, E. 2002. Democratic Theory and Network Governance. Journal Administrative Theory \& Praxis Volume 24 No. 4 , 693-720.

Peraturan Perundang-undangan

Undang-undang Nomor 7 Tahun 2017 Tentang Pemilihan Umum

\section{Lain-lain}

Website Resmi Bawaslu http://jdih.Bawaslu.go.id/

Data Pelanggaran Pemilu Tahun 2019. 2019, Bawaslu RI.

Hasil Wawancara dengan Ali Imron Kepala Subbagian Hubungan Antar Lembaga Bawaslu RI, 2019 